\title{
How Marriage Became One of the Sacraments: The Sacramental Theology of Marriage from Its Medieval Origins to the Council of Trent
}

Philip L ReYNOLDS

Cambridge University Press, Cambridge, 2016, Cambridge Studies in Law and Christianity, $x x x+1051$ pp (hardback £99.99) ISBN: 978-1-107-14615-0

Philip Reynolds, Aquinas Professor of Historical Theology at Emory University in Atlanta, Georgia and a senior fellow of Emory's Center for the Study of Law and Religion, quips in his introduction, 'I realized before I started writing this book in 2003 that it would have to be very long' ( $\mathrm{p} x \mathrm{xv})$. The table of contents is 11 pages long, divided into 20 chapters with 100 subdivisions; the 'overview of the entire study' promised in the introduction is itself 98 pages. Any attempt to be comprehensive in reviewing this book would make the review expand far beyond what any editor would permit. It is a rare reader who will sit down and read this volume from start to finish.

Although Reynolds indicates that his original intention was to trace the development of the theology of marriage from the twelfth century through to Thomas Aquinas, a period of about a century and a half, the central issues involved particularly what constitutes a sacrament and the role that consummation plays (in bringing marriage about, as well as on matrimonial permanence) continued to evolve, and to be discussed and elaborated up to the definition of marriage as a sacrament by the Council of Trent in Session XXIV (1563).

These starting and stopping points are by no means arbitrary. Reynolds amply demonstrates that the theological authors at the beginning of the twelfth century (and, quickly, the canonical authors as well) significantly re-interpret the patristic teachings on marriage, particularly Augustine. This takes on greater significance as the understanding of what a sacrament is undergoes a reformulation: marriage, alone among the seven sacraments defined by Trent, exists as a natural (non-sacramental) as well as a sacramental reality, and attempts to identify how, exactly, marriage was instituted by Christ challenged the creativity of the theologians. Other sacred rites considered 'sacramental' by earlier authors, such as religious profession or the coronation of a monarch, were dropped from the list until only the now established seven remained. The fact that marriage was retained among these seven by the Council of Trent owes as much to the sixteenth-century Reformers' understanding of, and enquiry into, what a sacrament was and was not, as it does to the writers of the classical period of scholastic theology and canon law. The author's review of the debates on marriage during Session XXIV of the Council of Trent is fascinating, thorough, admirably critical and well worth the effort and stamina needed to get to that point in the narrative. 
It is intriguing in all of this to see how important, not to say pivotal, the issue of clandestinity was to the medieval understanding of marriage. By the end of the period, it seems to be a central preoccupation. Reynolds here provides a very full consideration of what might be considered the sociohistorical background: given that by the close of the twelfth century, the fact that marriage was brought about by the consent of the parties given de praesenti was fairly well established, neither a public ceremony, nor the presence of a priest, parents, relatives or witnesses was necessary to create permanent matrimonial obligations and secure approval from the ecclesiastical hierarchy: 'Medieval clerics, canonists, and theologians did not celebrate the possibility of marrying clandestinely ... although they reluctantly accepted that there was no way to make them invalid' (pp 981-2).

Trent's famed decree Tametsi thus re-interpreted marriage yet again, requiring the 'canonical form' of the exchange of consent before an authorised minister and two witnesses for validity, establishing norms that survived for the next 400 years. As an aside, it seems strange, even ironic, that this requirement, which was originally intended to preserve the validity and sacramental character of as many marriages as possible, had become by the twentieth century a means to declare as many marriages as possible invalid, almost through a technicality (where a Catholic, bound to the canonical form, who marries civilly or without the requisite canonical formalities, can have the marriage declared invalid). Thus, tens of thousands of marriages involving at least one Catholic are now quickly declared invalid every year through an administrative process, avoiding any formal judicial process - a result surely not intended by the Council or the mediaeval authors. The sea change marked by Tametsi has turned into a tsunami, and current developments in the Catholic Church surely indicate that the modern movement, when clandestinity can hardly be considered a pressing issue, is further away from its sixteenth-century origins.

It is difficult to suggest how this work could be improved without also being made unmanageable, but the absence of a consideration of matrimonial litigation is regrettable. The number of scholarly studies of marriage trials across Europe is increasing year by year, and it would be interesting to see how the theories elaborated by the theologians and canonists translated into practice. To what extent were the theological and intellectual developments of the period under discussion actually established and accepted on the local level? How frequently did lay litigants access the ecclesiastical courts, and how did this differ across Europe?

This is not an easy book to approach, both because of its sheer size and its completeness. Nevertheless, Reynolds' approach will reward richly any reader 
who invests time and attentiveness in this magisterial and comprehensive synthesis of history, law and theology.

W Becket Soule OP Griffin Professor of Canon Law, Pontifical College Josephinum Columbus, Ohio doi:10.1017/So956618X18000583

\section{Church and State in Scotland: Developing Law}

FRANCIS LYALL

Routledge, London and New York, ICLARS Series on Law and Religion, 2016, xiii +239 pp (hardback $£_{120.99)}$ ISBN: 978-1-4094-5064-1

This is a welcome addition to Scottish literature on the relationship between church and state. In recent years there have been useful works which address this topic, such as the late Lord Rodger's study of the Disruption of 1843 (The Courts, the Church and the Constitution (2008)) and Dr Finlay Macdonald's short history of the Church of Scotland (From Reform to Renewal (2017)). Professor Lyall's contribution takes a broader perspective, looking at the law in relation not only to the established church but also to other denominations and also discussing the relationship between religion and legal regulation in modern society.

After an introductory chapter, Chapter 2 contains a brief overview of the Church of Scotland from the start of the Reformation in 1560 until the events which led to the Disruption of 1843. Lyall portrays the origins of the Disruption in the conflict between the Crown's attempts to control the Church and the idea of a church which was truly independent of the state, an idea which was included in Andrew Melville's Second Book of Discipline, which the General Assembly approved in 1578 .

Chapter 3 recounts the sad history of the unnecessary conflict between church and state which led to the Disruption and its aftermath. The conflict was manifested in court cases about the right of patronage, which the civil law treated as a right of property, and the asserted right of a congregation to nominate and appoint its own minister. When in 1834 the Evangelical movement gained a majority in the General Assembly of the Church, it passed what came to be called the Veto Act, prohibiting the appointment of a minister to a congregation against the will of the people. In the same year the General Assembly passed the Chapel Act, which gave full membership within the court structures of the Church to the ministers of new churches which had been created within existing parishes in order to cater for social and demographic change. Nine years of 